\title{
Polyface in Paradise: Exploring the Politics \\ of Race, Gender, and Place
}

\author{
Kalissa Alexeyeff and Yuki Kihara
}

\begin{abstract}
$\mathrm{T}_{\text {his }}$ his article arises from critical conversations about the politics of place that began in 2015 at the "Worlding Oceania: Christianities, Commodities and Gendered Persons in the Pacific" conference in Canberra, Australia. At the conference, anthropologist Kalissa Alexeyeff and Samoan artist Yuki Kihara both spoke on their research, which deals with overlapping themes of art, colonial imaginaries, gender, and representation. Both discussed the trope of Pacific paradise in Western and Pacific imaginaries. Alexeyeff talked about how images of tropical paradise were used to decorate homes of Cook Islanders living in Aotearoa/New Zealand. These included poster-sized pictures of sandy, palm tree-lined beaches and tourist-promotion leaflets of smiling Polynesian dancing girls. The utilization of these images, she argued, enacted a repossession or repurposing of the paradise trope to express longing and nostalgia for home back in the Cook Islands (Alexeyeff 20I6). Kihara spoke about her photographic series, Where Do We Come From? What Are We? Where Are We Going? (Kihara 2013), in which she dresses in Victorian mourning wear and poses at iconic sites in Sāmoa. One image in the series is of a paradisiacal tourist beach. Kihara discussed how her Victorian figure "haunts" this beach, grieving for local lives lost at this spot in 2009 as the result of Tsunami Galu Afi. Kihara's work repossesses the generic and timeless tourist paradise in order to thoroughly embed it in the social-historical memories of a particular landscape.

This conference experience led the authors to further collaborative engagements that took place across countries, at various academic conferences and art exhibitions, and through co-participation in the Master of Development Studies program at the National University of Samoa in 2016. We first discussed Kihara's work Der Papālagi, the subject of this article, in Melbourne in 20I6. The photographs that comprise this work
\end{abstract}

The Contemporary Pacific, Volume 30, Number 2, 329-353

(C) 2018 by University of Hawai'i Press 
also reverse and reconfigure images of paradise by placing Westerners in "traditional" garments in deliberately anti-paradisiacal urban locations in Apia, Sāmoa. While staring at the photographs, we brainstormed ideas and discovered in these exchanges our mutual interests in dress, crossdressing, and embodied performance.

Kihara's Der Papālagi deals with issues of cross-cultural masquerade, racial crossing, and cultural appropriation. The novel that inspired this work was a collection of speeches allegedly made by a Samoan chief, Tuiavii, in the early twentieth century. As we explain in the next section, this work is now considered to be a literary hoax penned by German author Erich Scheurmann. In one discussion, we talked about the overlaps between Scheurmann's book and the embodied performance of anthropologists during fieldwork. Kihara challenged Alexeyeff to think about how her experience of fieldwork research on dance in the Cook Islands had parallels to Scheurmann's masquerade. Performing with a dance group while wearing a coconut bra and grass skirt, modeling for Tav Pacific (a Cook Islands clothing company), and dancing in competitions and fund-raisers in front of local audiences were not just humorous tests for Alexeyeff but also part of a serious education in the embodied performance of Cook Islands femininity. While Alexeyeff would like to see her fieldwork cross-dressing as co-constituted with research participants and thus different from Scheurmann's masquerade and from Kihara's choreography of German-Samoan chiefs in her work, both of us want to connect the awkward, embodied nature of fieldwork to the politics and ethics of knowledge production in anthropology as well as to issues of cultural appropriation in literature, art, and other fields of representation. In coauthoring this essay, we step further into what we believe is an unsettling but ultimately productive space, hoping to generate an ongoing intellectual dialogue on the politics and poetics of place, race, and gender. We offer this description in the hope that it inspires other artistic and academic collaborations and engagements (see also Tengan and Roy 2014; Tamaira with Fonoti, this issue).

\section{Convent Street, Apia, 2016}

On 23 November 2016, the Walt Disney animated film Moana premiered in the United States and Sāmoa. A few weeks later, the director, producers, and Auli'i Cravalho, who voiced the lead character, attended a special red-carpet event at the Apollo Cinemas in Apia. The response to the film 
in Sāmoa was overwhelmingly positive; screenings were full and people described feeling proud that Pacific culture was "being put on the map" (TheCoconetTV 20I6). Some felt that the film showed the positive side of Samoan culture and liked that it paid tribute to Polynesian ways of life, art, and craft and voyaging traditions. Speaking to these themes, a mutual Facebook friend posted a review that emphasized the positive message of Moana for young brown girls: "Just got back from the movies with our girls here in Samoa. It's not every day you get to see characters on the big screen that look like them, that inspire fearlessness with love, bravery, and intellect. Islands and oceans filled with alofa. At the heart of it all-this was 'herstory' of a brown island girl that dared to go beyond the reef. I loved Moana, as did my girls" (Audrey Brown-Pereira, 25 Nov 2016, shared here with permission). These reactions differed markedly from some of the criticisms of cultural theft and distortion outlined in Mārata Tamaira and Dionne Fonoti's article (this issue). How are we to understand these different views? In this essay, we explore the politics of the line between cultural appropriation and appreciation. We ask the questions: Who crosses this line? How and when is the line crossed? Who legitimizes some crossings and not others?

To engage further with these questions, we need to leave the Apollo theater and walk fifty meters down Convent Street to look up at the digital advertising billboard above the Maxkar stationery shop. Here, a few days before the Moana red-carpet event, Kihara premiered her video work Der Papālagi (The White Man). Like Moana, this work presents audiences with images of cultural appropriation; in this case, Der Papālagi features Europeans dressed up in Samoan ceremonial clothing. Kihara's work did not receive the same level of acclaim or interest as Moana, however. No doubt this is partly because of the different genres-a mainstream, bigbudget Disney film versus a video-art screening_and the different "messages" that the films present. The Disney movie is a celebratory portrait of Polynesian identity and culture, uncomplicated by contemporary realities of structural racism and global warming, although clearly contextualized by them. In contrast, Kihara's work is deliberately provocative, confronting audiences with questions about racial identity. In Sāmoa, Der Papālagi generated a critical response that was framed in terms of cultural appropriation, the main criticism being the inappropriate use of customary dress. In Aotearoa/New Zealand, however, Der Papālagi was received with critical acclaim from the Samoan diaspora and art critics. Like much of Kihara's work, Der Papālagi has received far less praise and enthusi- 
asm in Sāmoa than it does abroad. These diverging responses to the two works present a puzzle about place-based articulations of race-one that we believe is worth investigating. This is difficult terrain that encompasses colonial histories, contemporary settler colonialism, and the global political economy, in addition to being intimately connected to personal experiences of identity and belonging.

We start this journey in Pacific paradise. Kihara's Der Papālagi is a critical reappropriation of a colonial novel of the same name, in which German author Erich Scheurmann masquerades as a Samoan chief who has a lesson to teach Europeans about the significance of the simple, more spiritual existence that nature's bounty offers. Kihara's work overturns both Scheurmann's impersonation and the trope of Sāmoa as a tropical paradise. She presents us with a racial cross-dressing, which creates a series of interlinked inversions of binary markers of race. As we aim to show, Der Papālagi creates a double vision through a layering of viewing positions, making explicit the politicized nature of the colonial gaze. These looking relations, we suggest, are also embedded in a politics of location, with someone always looking at someone else from a specific place. By locating these politics, Der Papālagi demonstrates how racialized structures of viewing are sources of power as well as highly manufactured in particular geographical and social spaces.

In exploring the politics of place, issues of cultural appropriation, and border crossings, this article engages with several related issues that link the themes of paradise and possession. The next section (The White Man) explores Kihara's visual reinterpretation of Scheurmann's I920 novel, which utilizes the trope of island paradise to promote a message of naturalism and virtue for an audience of post-World War I Germans who were facing poverty and rapid industrialization. Like the novel, Kihara's images speak to colonial histories and their contemporary circulation in the global industries of tourism and mass entertainment. However, paradise as seen through Western eyes is nowhere to be found in the urban locations that Kihara chose to stage her photographs of the white chiefs. In the following two sections (Racial Crossings and Shifting Views), we explore the inversions and critical reappropriations of racial categories in Kihara's work as they serve to destabilize racial boundaries and the hegemony of the white imperial gaze. The final section (White Natives) returns to questions of social geography and the politics of location, bringing us back to Convent Street and the public screenings of Kihara's work and Disney's Moana. 


\section{The White Man}

Yuki Kihara's Der Papālagi (The White Man), produced in 2016, comprises an eleven-minute video and five still photographs (see figures I and 3). The photographs are of two white people who are dressed in ceremonial Samoan clothing and stand stiffly, as if frozen, in several locations around Apia, Sāmoa's capital and largest city. The video records the reactions of local Samoans to the couple and the film crew. The white man and woman are Christian and Barbara Durst, German expatriates who have lived in Sāmoa for twenty-five years. They are adorned in the high-rank clothing of the tāupou (daughter of the high chief) and tulāfale (speaking chief), and their garments are made from 'ie tōga (fine mats) and siapo (tapa). Barbara's headdress is a tuiga, intricately crafted from feathers, pearl shells, and hair. Both wear necklaces that denote their status: an 'ula nifo pua'a (boar tusk necklace) rests around Barbara's neck, while Christian wears an 'ula fala (red pandanus necklace) and carries a fue (flywhisk). Both also carry a ceremonial staff.

Kihara's work is a response to Der Papālagi (The White Man), Erich Scheurmann's I 920 literary hoax. Ostensibly, the novel is Chief Tuiavii's ethnography of Western-particularly German-modernity, as translated by Scheurmann. Tuiavii's insights are supposedly drawn from his experiences as a member of a performance group who traveled to Germany in the late r8oos to take part in Völkerschau-ethnological exhibitions, or human zoos-which brought people from various German colonies to perform demonstrations of their everyday and ceremonial lives for metropolitan audiences (Thorde-Arora 20I4).

Despite still being published as the speeches of Chief Tuiavii as recorded and translated by Scheurmann, there is no doubt that Der Papālagi is a fictive account (Scheurmann 2007). In the book, Scheurmann takes literary possession of a Samoan chief in order to diagnose the spiritual and moral decay he perceives as enveloping Europe. To evoke "native innocence," Der Papālagi is written in naive, almost nonsensical prose, describing an Eden where "natives" want for nothing, as the tropical, bountiful land of Sāmoa provides all. Samoans' harmonious relationship with nature makes them joyful and content, in contrast to "the White Man," who is pale and tired due to his obsession with work and, most importantly, "round metal and heavy paper," that is, money (Scheurmann 2007, 69). Scheurmann has Chief Tuiavii speaking in incredulous tones about the burden of Euro- 
pean clothing, the cold and constricted stone housing, and "the serious sickness of thinking" (2007, I7I).

As a critique of the ills of civilization, Scheurmann's work sits in the well-worn "paradise lost" genre of faction (a mixture of fact and fiction) that has continued to be popular with Euro-American audiences who desire green and "natural" alternatives to their industrialized and urban existence. ${ }^{1}$ The book purports to offer a way out of the constrictive artifice of industrial society and a return to a simpler spiritual morality-a "return to inner values" (Scheurmann 2007, 65). The desire for a terrestrial paradise to reorient the existentially weary urban dweller no doubt contributes to the willful suspension of disbelief that is required to read Scheurmann's novel. Here, the spatial trope of paradise is coupled with the temporal trope of nostalgia within the context of modernity. The trope of "paradise lost" serves to register anxiety about rapid social change, the rise of the city, and its corresponding environmental impact (Deckard 2010, 5). Such paradise discourse also enables the violence of colonial occupation to be obscured and for attention to be diverted from anticolonial activism. For example, Scheurmann visited Sāmoa in I9I4-I9I 5, when the Mau movement for Samoan independence was actively resisting foreign domination. Moreover, since the I 830s, foreign trade and the impact of Christian social norms on dress, housing, and morality have made a significant impact on the Samoan way of life. At the time of Scheurmann's visit in I9I 5, the main town of Apia was a burgeoning hub of settler colonial activity, but none of this is mentioned in the novel.

Kihara's Der Papālagi performs a series of critical reappropriations and deconstructions of the original papālagi story. First, she exposes Scheurmann's hoax by placing the German couple in Samoan ceremonial dress; this intervention places the appropriation of Tuiavii's identity in plain view. Second, she enables Scheurmann's fantasy of a paradisiacal Sāmoa to come true. Christian and Barbara Durst are living Scheurmann's dream, and they describe their involvement in Kihara's work as a deep honor and testament to their respect for a "culture still alive and vibrant" (Christian Durst, pers comm, I 5 Nov 20I7). Third, Kihara disturbs the original paradisiacal fantasy by placing the white, German protagonists, or avatarsdressed as they are in regal clothing and regalia-amid everyday scenes of urban life in Sāmoa. These scenes include a marketplace, a street corner at a busy intersection, a supermarket, an outdoor plaza, and a café restaurant. In these spaces, Samoans are busy checking their phones, eating lunch, walking to work, and shopping. The chiefly German figures look 
most at home at the Fugalei market, amid stalls selling printed materials, coconut oil, and local fruit and vegetables. At the Samoan National Provident Fund (SPNF) plaza, open-air vendors sell cheap, imported toys and sunglasses, and the chiefly couple appears starkly anachronistic among the colorful plastic items. Inside Frankie's Supermarket, they take up much of the space in front of an aisle stocked with imported tinned fish and meat, serving as a clear counterpoint to Scheurmann's paradisiacal images of health and vitality born from a life lived close to nature.

The video component of Der Papālagi documents the reactions of local observers-who are ultimately participants in Kihara's work-toward the immobile German chiefs in these urban tableaux. These reactions constitute a rupture between local and foreign forces by juxtaposing Samoan traditional authority with the trade, labor, and consumption associated with global capitalism. At first, it seems, people do not know what to make of the two in costume; they are unsettling and yet, at the same time, transfixing. In many instances, the avatars are simply ignored. Sometimes,

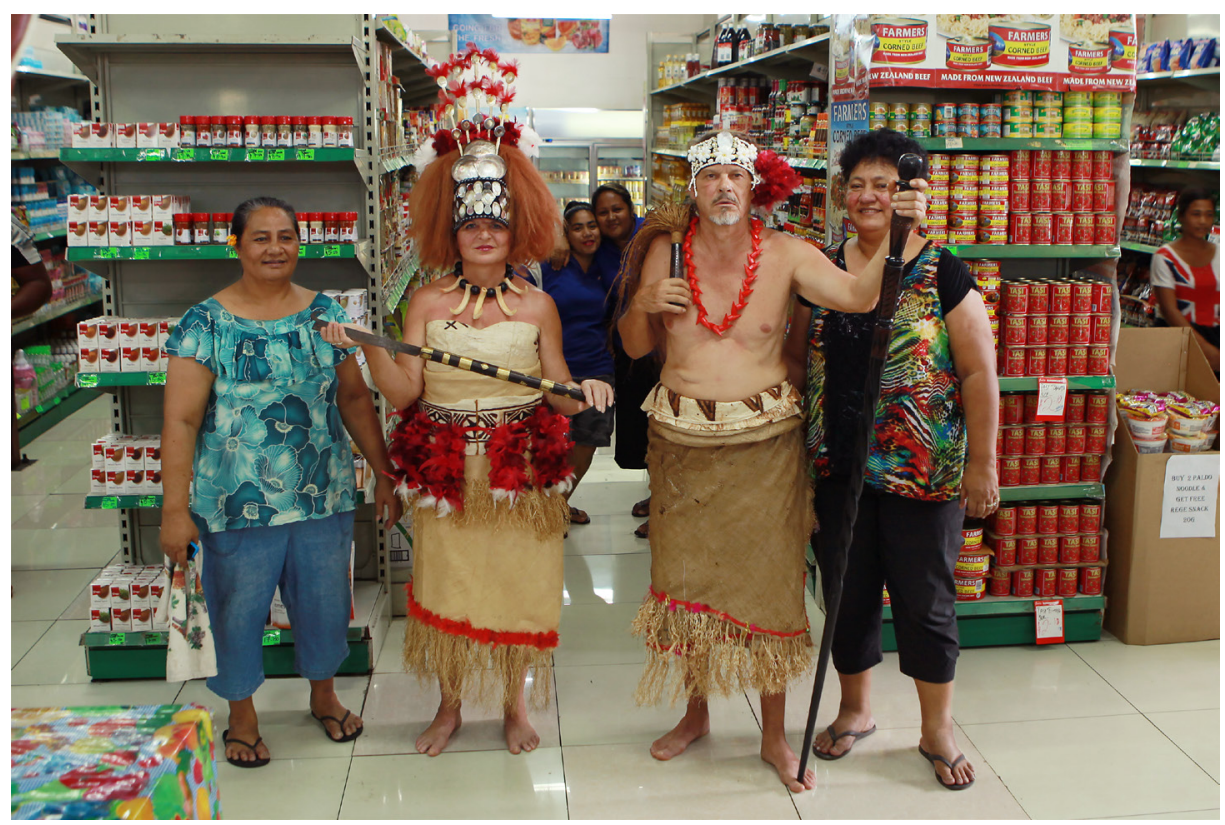

Figure I Der Papālagi performers posing with shoppers at Frankie's Supermarket in Apia, Sāmoa, 20I6. From Der Papālagi (The White Man) series by Yuki Kihara (20I6). Photo reproduced with permission of the artist and Milford Galleries Dunedin, New Zealand. 
after a slight hesitation, people just walk past or around them as they continue their shopping. Only young children stare at length at the chiefly couple, as well as at the camera crew. Others react to the couple as if they were "living statues," which many no doubt have seen performing on streets around the world. Most do not engage directly with them, nor do they in any way attempt to make them move or talk. Instead, passersby take selfies or record footage of the German chiefs on their phones. Most amusing to see is the "dance" Samoan subjects do to get in place next to the German Samoan statues for photos, complete with "shaka" and "gangsta" hand gestures. We see, for example, a hand holding a phone in the right corner of the video, waving a spectator to move closer to the chiefly statues in order to capture a souvenir of these exotic curios. These moments echo and invert the original staging of colonial portraits of Samoan people.

In this regard, Kihara's work references The Couple in the Cage by performance artists Guillermo Gómez-Peña and Coco Fusco (I992-I994), who presented themselves in a cage as "undiscovered Amerindians" to unsuspecting audiences. Spectators' reactions to and engagements with the couple were compiled in a similarly titled film about the performance (Heredia and Fusco 1993). Kihara's Der Papālagi also operates as an inversion of this work in that the white couple performing as Samoans are observed and subjected to the gazes of Indigenous Samoan spectators.

White people masquerading as Samoans evoke earlier colonial appropriations of native bodies. Much of Kihara's artistic practice revisits colonial political economic relations with forensic visual precision. In Culture for Sale (Kihara 2012), she referenced the Völkerschau of the German colonial period, linking it to contemporary cultural displays that occur in the tourist industry. Performers dressed in Samoan ceremonial wear stood immobile on raised pedestals until audience members inserted money into nearby slot machines, thereby activating a brief performance before a return to statue-like poses (Treagus 20I6). Similarly, A Study of a Samoan Savage (2015) is a photographic and video series of the demigod Māui that documents the "science of race" and its clashes with the divine. The work shows Māui's naked body being documented through anthropometry (the measurement of physical attributes in order to hierarchically classify humans) and in stop-motion photography. In this work, Kihara posed the questions: How does science "measure" the divine? Are spirituality and science fundamentally opposed?

The staged reversals achieved through dressing the Germans in Samoan 
regalia and by placing them in urban, modern settings create an antiparadise. In the video, we witness Samoans' responses to Der Papālagi as a combination of avoiding and sneaking or squeezing past the chiefly figures, as well as seeking opportunities for selfies and group snaps in which friends flank the German couple. These varied responses confirm the logic of Kihara's transposition of figures and locations so as to position the masquerading Westerners as alien visitors from a fictive past in and among the built-up environments of modern work and consumption. They also highlight how thoroughly the everyday practices of work, conviviality, and consumption render the artwork, for most, as a curiosity or as an obstacle best met and responded to with nonchalant ambivalence. This is a complex version of "Polyface" that makes visible the embodied cultural appropriation presented in Kihara's Der Papālagi.

\section{Racial Crossings}

Cross-cultural impersonation is an established tradition in Euro-American art and cultural production. Scheurmann's Der Papālagi draws on this tradition, which most often entails a white (usually male) author masquerading as a wise "native" who possesses seer-like abilities that enable him to diagnose the ills of "modern" European society. ${ }^{2}$ The tales are generic and the geographies highly substitutable. Indeed, not only has Scheurmann's book been found to be an impersonation of a Samoan chief, it also draws heavily from Hans Paasche's The Research Journey of the African Lukanga Mukara into Innermost Germany (I988 [I9I 2-I3]), a fictional account based on Paasche's experiences in Africa, written as letters from Mukara, an African man, critiquing German society (Wattie I992; Senft 1999).

There are other, related variations on this theme of impersonation. Early colonial reports throughout the Pacific discuss "parties" in which settlers would "cross-dress" in the garb of local people. The striking image of New Zealand sailors from a warship dressed as Cook Islands "warriors" killing other sailors (see figure 2) is but one glimpse of these "playful" moments. Here, bodily possession connects to political possession, aestheticizing the violence of colonial encounters (Jolly I997, 99). Similarly, in the film Cannibal Tours (O'Rourke I988), visitors on a cruise ship in Papua New Guinea, complete with face paint, capture a contemporary moment of cultural appropriation that is at the very least ethically unsettling but also deeply fascinating (Silverman 20I3). The same could 
be said of anthropology itself, insofar as it is based on extended periods of residence in communities that requires anthropologists to "go native" and adopt local social norms and dress in order to fit in. The parallels between colonial and neocolonial forms of cross-dressing, evidenced in these examples of colonial diplomacy, tourism, and anthropology, remind us that racial crossings are never neutral but rather that they embody the structural power relations that have enabled these encounters and exchanges.

What does cross-cultural dressing do for white people? Many social theorists have emphasized the conservative intent of cross-dressing or drag. Most famously, Judith Butler, who took issue with utopian accounts of gender performance that drew on her analysis in Gender Trouble (I990) and that considered drag as straightforwardly subversive of gender norms. In later work (Butler I993), she emphasized how most drag performances (especially those performed by heterosexual and white bod-

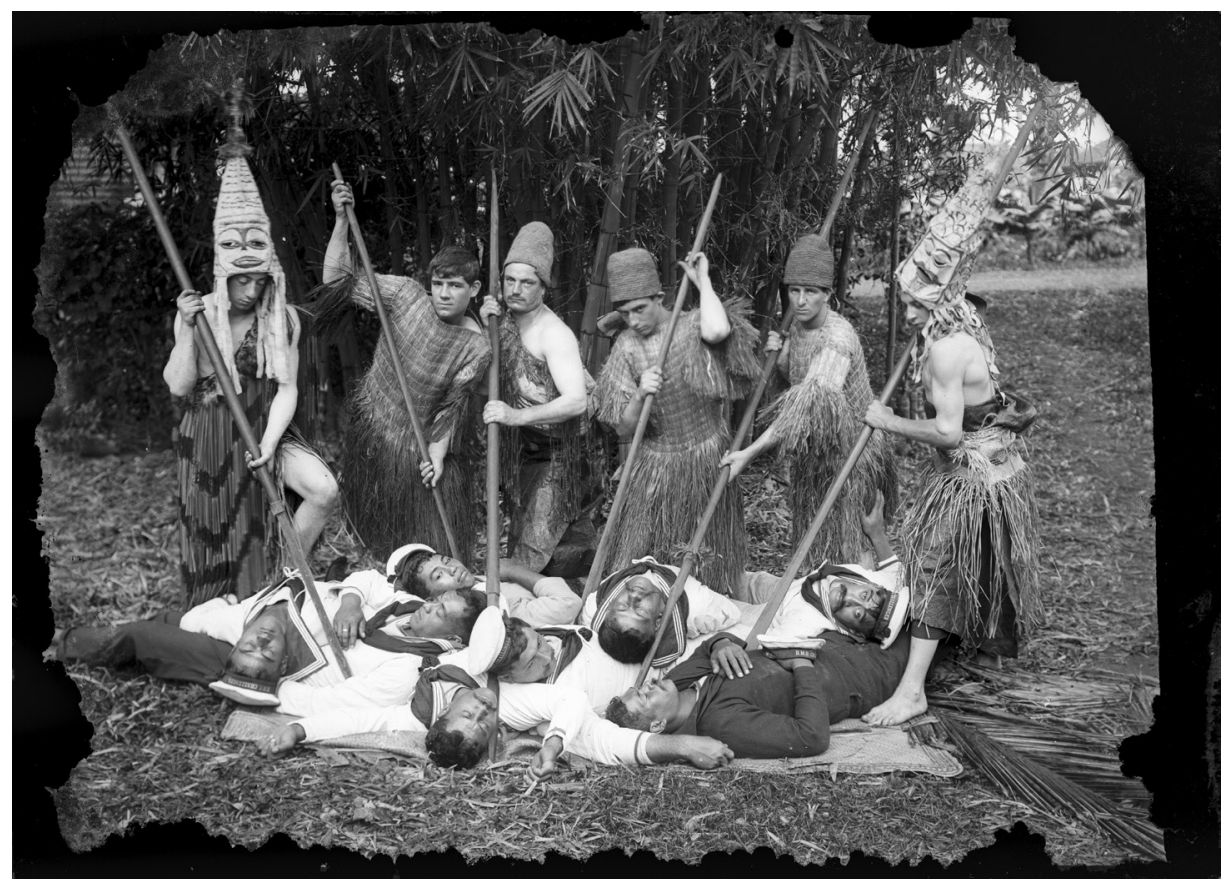

Figure 2 A group of sailors from the warship gmv Mani Pomare during a visit to the Cook Islands. They are dressed up to look like Cook Island "warriors" and are pretending to kill other sailors. Photo by George Crummer, I9I 2, and reproduced with permission of Te Papa Tongarewa, Wellington, New Zealand. 
ies) work to contain and resolve homophobia and racism rather than subvert these hegemonic categories. Cross-dressing as an "other" (not-male and not-white) aims to police and fortify boundaries of heterosexuality and racial segregation. Drag, wrote Butler, is "at best, it would seem ... a site of certain ambivalence" (Butler I993, 85-86; see also Alexeyeff 2000, 2009).

"Blackface" minstrelsy, a nineteenth- and twentieth-century theatrical practice, provides an instructive comparison. Emerging from the material conditions of colonialism, "blackface" performs the precarious division between white and black, both evincing the permeability of racial classification and redrawing the lines of demarcation. Its appeal lies in the "haunted realm of racial fantasy," wherein possession expresses desires of mastery and control (Lott 20I3, 4). It perpetuates racism while popularizing "black" music, art, and performance traditions.

Scheurmann's Der Papālagi is a clear-cut example of "Polyface"; it operates like "blackface" or "high het [heterosexual] entertainment" (Butler 1993, 85), fortifying the boundaries of the self through a foray with difference, leaving white heterosexual privilege intact. As in many previous works, images of European decay and Pacific paradise circulate in Scheurmann's book and enact key fears and desires of a particular time and place. Der Papālagi responds to the rapid social change brought about by industrialization and the fallout of German defeat in World War I. By adopting the guise of a Samoan chief, Scheurmann attempted to "be" his real self and envisage the paradise he wished to create. Self-obsession is also made painfully clear in the synopsis of the work that appears on the book's back cover: "Tuiavii, a Samoan chief, traveled to Europe at the turn of the 2oth century and wrote a commentary condemning the very foundations of Western society. ... By looking at ourselves through Tuiavii's eyes we are saddened by the loss of simplicity and humanity in our society. Yet each page, filled with Tuiavii's insight, brings us a step closer to the truth and, ultimately, to understanding ourselves" (Scheurmann 2007).

In contrast, Kihara's Der Papālagi exposes Scheurmann's literary masquerade by dressing up white people in Samoan chiefly garments. The inversion is completed with the placement of the figures in locations that would horrify Scheurmann and the many fans of his work and undercut their purposes. The landscape is urban Sāmoa: paved roads, high-rise buildings, and busy streets of consumers. The locations where Kihara's chiefly couple are placed are local rather than tourist sites; there is no 
beach, palm tree, or cocktail in sight. Instead, we see mobile phones, cars, religious iconography, Chinese plastic accessories, and processed food.

What occurs in Kihara's repossession? Butler argued that drag-performed by certain people, in certain ways, and for certain audiences-has the potential to both denaturalize and reinscribe hegemonic norms (Butler I993). She based this on her reading of Paris Is Burning (Livingston I990), a documentary film that explores the Harlem drag balls of the I980s and in which the black and Hispanic participants perform crossings of race, class, and gender. Denaturalization, however, does not imply liberation but may instead highlight an "irresolvable tension" (Butler I993, 9I). Homi Bhabha usefully termed this politicized tension as "double vision" created by the "menace of mimicry," which disrupts the hierarchies of race and gender categories (1984, I19).

Racial and gender crossings that invert the mobility of white male signifiers are a long-standing component of Kihara's work. Dress is an important signifier of these crossings in much of her art practice. As the title of her midcareer survey exhibition Undressing the Pacific suggests, dress is used strategically to unsettle, and potentially subvert, neocolonial histories and epistemologies as well as contemporary gender, sexual, and cultural identity politics that shape the Pacific region and Sāmoa in particular (Kihara and Poland 2013). In the haunting Where Do We Come From? What Are We? Where Are We Going? (Kihara 2013), which references Gauguin's painting of the same title, Kihara dons Victorian mourning dress to perform as her alter ego, Salome. In a black, heavy, full-length dress, Salome visits sites of mourning such as the Mau monument, a replica of the headquarters of the Mau resistance movement of the late nineteenth and early twentieth centuries. In another image in this series, mentioned in the introduction to this essay, she stands on the beach at Lalumanu, a prime tourist destination and the site of the monstrous Tsunami Galu Afi in 2009. Salome stares out to sea, reorienting the viewer's gaze away from the picturesque of paradise, enveloping the view in the sadness of the lives lost (at least I89 in Sāmoa, the majority from this part of Upolu). She gazes beyond the horizon to the challenges posed by global warming, the effects of which are disproportionately borne by inhabitants of island nations.

In another version of cross-dressing, Kihara's 2015 work Them and Us (with Jochen Roller) is a dance production, exploring the formal similarity of the Samoan fa'ataupati dance and the German schuhplattler-both are forms of "slap dancing"-which have no known relationship with each 
other. This performance premiered at the Sophiensaele Theater in Berlin, with the dancers wearing lederhosen or grass skirts and moving seamlessly between the two dance styles that unravel distinctions between "them" and "us," and object and subject (Roller and Kihara 2015).

Situated in this broader corpus, it becomes evident that Kihara's Der Papālagi is a work of cross-cultural drag that provides commentary on a novel produced within the context of German imperialism and that nation's instability and poverty after World War I. It also references a long history of Euro-American appropriation of "the other" in art and literature as well as in popular culture forms (see Torgovnick I990 for an early, insightful text). Kihara's work serves as a further "undressing" of the colonizing impulse, revealing its extractive intent, which demonstrates little interest in Indigenous populations except for what they can do for the weary, disappointed colonizer.

Other crossings and inversions become more central when we consider the photographs in concert with the video component of Der Papālagi. Local Samoans and others who participated in the video presumably have never heard of Erich Scheurmann, and many showed little interest in his work if they do know: "Why would Samoans be interested in a white guy dressing up as a Samoan!?” was a common response. While Kihara's work may not resonate as a work of literary impersonation, local reactions to the German-Samoan chiefly couple certainly provided commentary on contemporary relations of classification and surveillance. These interactions inverted the Samoan-non-Samoan interactions that are played out in the neocolonial settings of a global political economy, which is most clearly encountered in Sāmoa through exchanges with tourists, expatriate residents, and representatives from multinational companies, and development and aid agencies. In Kihara's Der Papālagi, it is the white people who have "gone native" and who are being surveyed. The Samoans who appear on screen are, by contrast, getting on with their modern, everyday lives.

\section{Shifting Views: Acts of Repossession}

"What happens when white people look at non-whites? What happens when the gaze is returned-when black peoples own the look and startle whites into knowledge of their whiteness? What mirroring processes (going both ways) take place in inter-racial looking?" (Kaplan I997, 4). These are opening questions from E Ann Kaplan's classic I997 text on interracial looking, Looking for the Other: Feminism, Film, and the Impe- 
rial Gaze. Cross-dressing and cross-looking are interconnected in Kihara's Der Papālagi series. In both the photographic and video components, the questions of who is looking at whom and how they are looking are crucial to apprehending the layers of "looking relations" that Kaplan's book describes.

The "imperial gaze," a long-established instrument of surveillance and knowledge production, is evident in Scheurmann's novel (Kaplan I997, xix). Scheurmann very likely first honed this gaze at the "human zoos" where colonial subjects were displayed in Germany in the late nineteenth century as scientific and popular curios. That Scheurmann traveled to Sāmoa on an advance from his publisher constituted a further act of colonial occupation. Here, his supposed "right to look" enabled him to claim possession of the mind and body of a Samoan chief. Under this guise, he enacted a white colonial perspective "as if it was no perspective at all" but rather a universally true diagnosis of human nature (Kaplan I997, 94). This seemingly neutral and omniscient gaze hides the specificities of race and gender; here, the imperial white male is unmarked and all-seeing.

But the imperial gaze, like the regimes it advances, is actually never all-powerful or all-seeing; it is always two-way (Jolly I997; Kelly I997). As a counter to Scheurmann's experience of the human zoo, we have the experiences of the real Samoan Chief Tamasese, who visited Germany in I9I 5 with at least twenty members of his family, ostensibly to perform dances, boxing contests, games, and kava preparation at the Hamburg Zoo. Tamasese, however, had little intention of staying behind the bars of his racial cage; he understood his role visiting Germans as a cultural ambassador rather than as an ethnographic display. In order to further diplomatic relations, he visited the former German governor of Sāmoa, Wilhelm Solf, and was presented to Kaiser Wilhelm and King Ludwig of Bavaria, presenting fine mats in accordance with the protocols of Samoan ceremonial exchange (Meleiseā I987, IO4-IO5).

Kihara's intervention similarly crosses the lines of race and gender and the associated or expected looking relations. White people are dressed as Samoan chiefs; they are frozen objects; their bodies are on display. The spectators are Samoans; they are active subjects, moving through the still photographs and video-frames, choosing whether to look at or simply pass by the immobilized chiefly statues. Der Papālagi reverses imperial looking relations, querying the omniscience of the white imperial gaze, and, by doing so, deterritorializing its colonizing intent. In Kihara's Der 
Papālagi, the imperial gaze of the early twentieth century is connected to the present-day "tourist gaze" (Urry I990). The temporal layering of colonial and touristic looking is enacted through a series of mind-bending twists that disrupt the Western imaginary of paradise. For example, in the video component, the "human zoo" is transposed from Germany to Sāmoa. In this transposition, instead of Germans looking at Samoans on display as signs of a "primitive" past or as a demonstration of colonial might, we are presented with white people in urban Sāmoa being observed by Samoans. This inversion suggests a different set of looking relations: Samoans observing white people as strange specimens from another place. It is not simply a mirror inversion - that would be white people dressed in Euro-American clothing (say, tourists in shorts and T-shirts). Instead, the figures are dressed in Samoan ceremonial clothing, thereby impersonating Scheurmann impersonating Chief Tuiavii in order to reveal such impersonations as fantasies. Concurrently, the living statues-these "white natives"-are subjected to a tourist gaze that mirrors and thereby parodies the looking relations of contemporary whites strolling around in their scanty clothes and staring at Samoans.

The similarities between tourism and anthropological fieldwork have been noted (eg, Alexeyeff and Taylor 2016; Errington and Gewertz I989). In this context, Kihara's work creates a sense of disquiet and, perhaps, embarrassment for coauthor Alexeyeff, who enthusiastically embraced the dress and demeanor of her Cook Island peers during her graduate research. Like the Samoan chiefs (both Scheurmann's chief and the Dursts), anthropologists participate in similar forms of crossing/cross-dressing that require consideration of the politics of their knowledge production. Our personal experiences suggest that cross-dressing anthropologists amuse local populations. Like the observers of Kihara's Der Papālagi on the streets of Apia, these performances are fascinating, making it difficult both to look and to look away.

But what of interracial looking from the perspective of Samoans? Samoans are used to being looked at, photographed, and otherwise observed by tourists (and other white surveyors, such as aid and development workers). They also have strategies for avoiding and shaping this gaze in ways that sometimes deflect, resist, or reorient this gaze. Like other residents of tourist destinations, Samoans are experts in both studiously ignoring and carefully observing-with surreptitious sideways glances-the surveillance of the tourist gaze. This type of looking is not simply a response to outsiders' looks but is also shaped by locally styled looking relations and surveillance 
techniques; "knowing one's place" in relation to hierarchically ordered others is fundamental to Samoan social relations (Tcherkézoff 2009; Anae 20I0; Latai 20I4). Unlike Western ideas of space as something neutral through which individuals move, Samoan individuals move through space in relation to other people. For example, the supermarket is not simply a place where individuals shop; rather, movement there as elsewhere is determined by socio-spatial relationships to other shoppers in terms of rank, status, and vāfealoa'i (reciprocal responsibilities and respectful relations expressed in space). Passing in front of older, and especially highranked people (such as chiefs, pastors, or politicians) at, say, the tinned fish aisle, requires acknowledgment through bowing, lowering one's eyes as passing, and uttering softly, "Tulou" (excuse me). ${ }^{3}$

Indeed, one of the film crew working on Der Papālagi recalled that, while filming, she noticed that the Samoans who passed by the white chiefs would not look directly into their eyes. She surmised that this was because their regalia conferred on them a chiefly status that requires avoidance of eye contact (Dionne Fonoti, pers comm, I2 Dec 20I7). Whether the

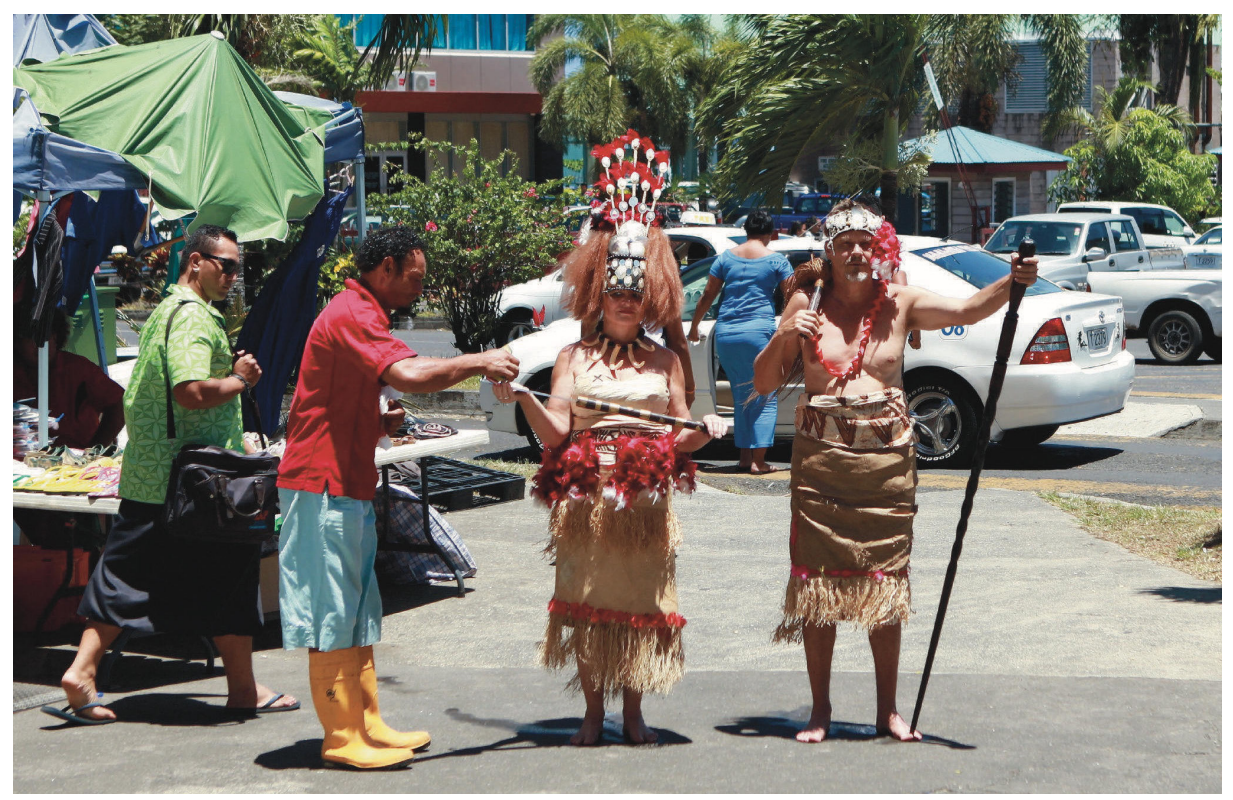

Figure 3 Der Papālagi performers and passersby on Convent Street in Apia, Sāmoa, 20ı6. From Der Papālagi (The White Man) series by Yuki Kihara (20I6). Photo reproduced with permission of the artist and Milford Galleries Dunedin, New Zealand. 
gaze was averted because the chiefly statues were white or because they were dressed as chiefs, most locals included in the video piece treated the "white natives" with nonchalance, continuing their shopping and eating after observing the pair and the film crew with a glance that lasted only a beat. But, as discussed earlier, many locals engaged with them as if they were living statutes, taking selfies, group photographs, or filming them. Little attempt was made to talk to them or otherwise interact.

In the video, only two Samoan men engage in an extended way with the white chiefly couple. At the Fugalei market a man-whose comportment and dress suggest that he may be a Samoan visitor from abroad-attempts to talk to the immobile Christian, coming close to his face to inspect him. On receiving no response, he gives up and takes a selfie that is captured wonderfully in a still image. Another man, whose rubber boots and apron suggest that he works at the fish market, walks with exaggerated gestures up to the couple and, with a humorously performative bow, places coins into Barbara's hand (figure 3). This sequence in particular enables a layered reading that blurs, or at least unsettles, racialized looking relations. The fish market man mocks their impersonation; he rewards their "show" with money, as is common tourist practice. It is common because performers (in both local and tourist settings) often incite the audience to show their appreciation by donating money at the end of a show. It is thus an act shaped by local Samoan protocols of performance and the demonstration of appreciation through giving money.

The multiple, perspectival layers of Kihara's Der Papālagi stretch across time and space to make direct connections between colonial and neocolonial structures. Here, German colonialism meets touristic gaze, albeit in a series of inversions and reversals aimed to skew dominant Western narratives of possession and control.

\section{White Natives}

A final element to Kihara's Der Papālagi was the public screening of the video on a digital advertising billboard in the center of Apia (figure 4). The work was screened 2-6 December 2016 and allowed observers on the street to become part of the spectacle both through watching the GermanSamoan chiefly couple and through watching other Samoans watching the couple. Reactions to the video component varied considerably; many did not know what to make of it and seemed nonplussed or bemused. Others laughed at the reactions of the Samoans who were filmed interacting with 
the German chiefly couple, overlaying their amusement and bemusement with those of the Samoans on the screen.

For some, the work was transgressive, raising questions about cultural appropriation of Samoan customs. These questions were not aimed at Scheurmann's novel but rather at the artist Kihara. Not only was dressing white people in Samoan ceremonial regalia considered misappropriation, but Kihara's racial identity as an 'afakasi (half-caste, in this case Samoan and Japanese) meant that, according to some critics, she was not entitled to make the work. In her opening night speech, Kihara made clear that the point of her Der Papālagi was to question the boundaries of race and of cultural appropriation. She recounted how people had said to her that having the German couple dressed as a tāupou and a tulāfale outside of a village or ceremonial context was culturally offensive. Kihara brought up this incident to the audience gathered at the opening and then queried this logic by asking, "How do we explain Samoans dressed as tāupou and entertaining tourists at a resort?" Kihara said that another person had broached a similar issue, stating that papālagi should not wear

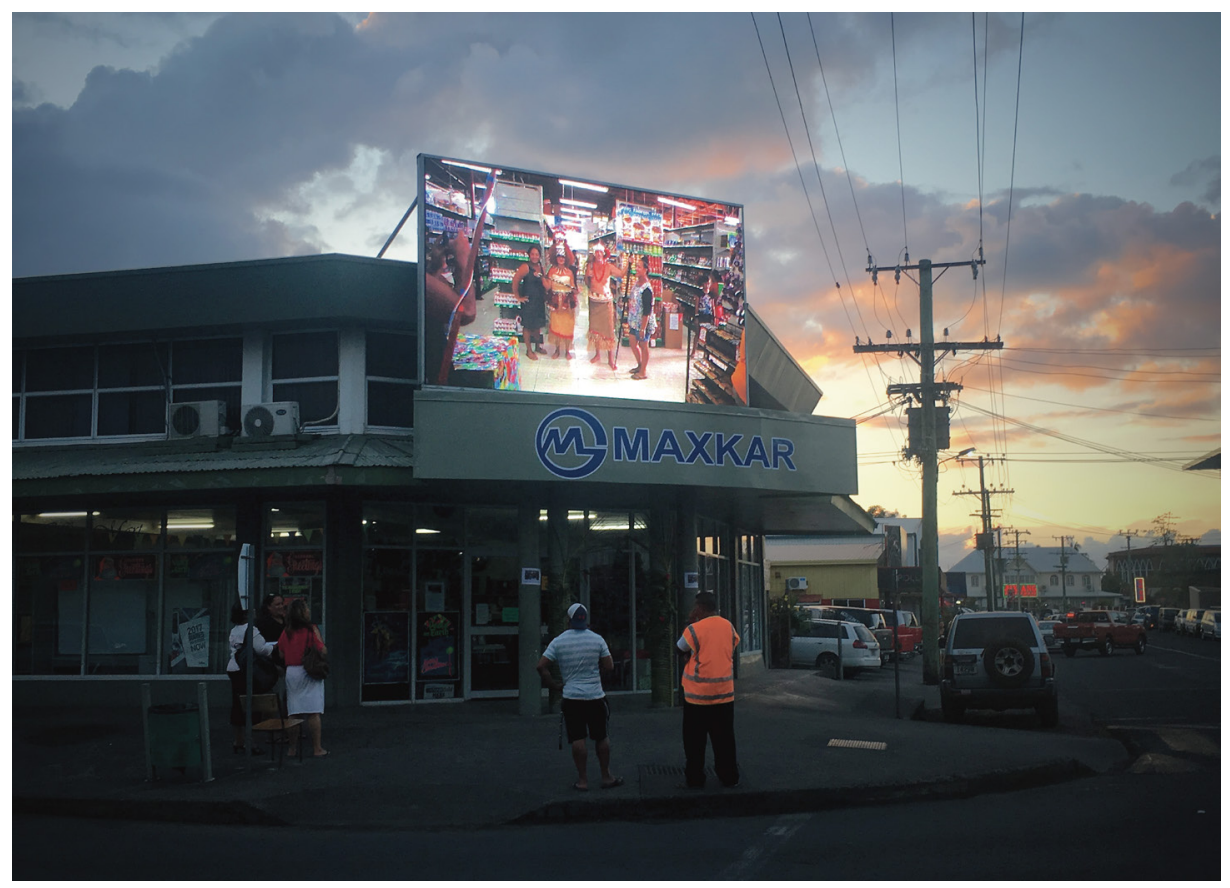

FIguRE 4 Watching Der Papālagi on a digital screen in central Apia, Sāmoa, November 2016. Photo reproduced with permission of Greg Dvorak. 
sacred Samoan regalia because they are not Indigenous Samoans. To this, Kihara posed a counter-argument, raising the matter of chiefly titles being bestowed on visiting male politicians: "How do we explain John Key (former prime minister of New Zealand) or Ban Ki-moon (former secretarygeneral of the United Nations) being given matai titles?" These provocations raised further questions about power relations in racial crossings: Who crosses, how, and when? Who legitimizes some crossings and not others?

These are more than questions of adornment, who wears what clothing, or who gets which tattoo. Kihara is also asking ontological questions: Where are the lines between brown and white? What constitutes the correct racialized body that counts as authentic? In this sense, Der Papālagi, as a work of cultural drag, does something more than just invert white and brown bodies: it queries the very essence of racialized demarcations of identity and ownership through embodied performance.

By using two German expatriates who have resided in Sāmoa for over twenty-five years, Kihara knowingly stepped into contestations over racial categories of belonging. In Sāmoa, "local" has a very specific meaning and is used to refer to Samoans raised in Sāmoa. It is not capable of being adopted by other types of Samoans, let alone non-Samoans. 'Afakasi Samoans are mixed race (most often pālagi and Samoan). Saina are Chinese Samoans who are not classified as 'afakasi because they are not white. Both terms are usually applied to those raised in Sāmoa. "Sāmoa mai fafo" is the term used to classify Samoans who reside in Sāmoa but were raised abroad; it also refers to Samoans who live in the diaspora (regardless of where they are born). And finally, "papālagi," the plural form of pālagi, is the term to describe white people. These shifting but powerful racial categories are used both to promote and restrict individual claims to ownership of land and positions of influence and status. These processes of racialization also map onto colonial histories and interactions between groups of locals, papālagi, and saina.

The cross-racial drag that Kihara's Der Papālagi performs ensures that the oppositions between papālagi and local go awry. This is further enacted through the layered viewing positions created throughout the work. In the photographs and video, Samoans look at "white natives" while in the public screening of the video. Another layer is added to these looking relations as Samoans watch other Samoans looking at the "white natives." These multiple perspectives illustrate the traffic in racial crossings-that "the gaze" is not all one way. The central place given to local 
Samoans' responses in both the video and billboard screening of Der Papālagi allows Kihara to connect with an emerging strand of scholarship that aims to provincialize whiteness, thereby demonstrating the historical and geographical variability of the term in relation to other residential groups (Okamura 1994; Ohnuma 2002; Rohrer 2010). In Sāmoa, whiteness is certainly associated with neocolonialism, wealth, and property, but it is never omniscient or unmarked.

Attention to the two-way exchanges and encounters operating in Der Papālagi goes some way to explain a final puzzle of the divergent reactions to Kihara's screening of Der Papālagi on the digital billboard at the same time as Disney's Moana showing at the Apollo Cinemas just down the street. Moana may also be usefully thought about as a form of cultural drag, or as a racial masquerade-with the white corporation "passing" as brown and Polynesian in order to expand its consumer base. Certainly, Disney's perpetuation of white supremacy deserves acknowledgment, but so too do other perspectives produce a range of engagements (Sandlin and Maudlin 20I5). In Sāmoa, audiences enjoyed and celebrated Disney's production, and yet these same audiences (perhaps passing by on the way to see Moana at the Apollo theater) may be heard criticizing the appropriation of Samoan culture in Kihara's Der Papālagi. How can these responses, which seem fundamentally at odds with one another, be understood? We have argued throughout this article that the politics of place plays an important role in contests about cultural appropriation. Categories and experiences of racial identity have a social geography; local and foreign configurations of these identities arise out of specific spaces and produce particular encounters and interactions. Acknowledging these complex configurations may assist in providing a further lens to scrutinize questions of appropriation and repossession and move toward more nuanced understandings of place-based articulations of race.

Der Papālagi invites a range of looking relations, viewing positions, and responses that are tied to broader, global economic and political configurations that express unequal relations (looking or otherwise) established in colonial relations and perpetuated in contemporary forms such as tourism and labor migration. Der Papālagi impels the viewer to make these connections. By engaging local Samoan audiences in her work, Kihara reveals how these relations are always two-way and how they may produce culturally coded exchanges that serve to unravel, if not displace, clear-cut narratives of cultural domination. 
$* \quad * \quad *$

THANK YOU TO A NUMBER OF PEOPLE who provided us with feedback on this essay, especially Audrey Brown-Pereira, John Cash, Christian and Barbara Durst, Greg Dvorak, Dionne Fonoti, Margaret Jolly, and Siobhan McDonnell.

\section{Notes}

I Scheurmann's Der Papālagi has been translated into at least ten languages and has sold well over one million copies (Senft I999, 65). For more information about Erich Scheurmann's life and work, see Wattie I992 and Senft I999.

2 The reader will no doubt be reminded here of numerous historical and contemporary examples of literary racial masquerade, such as Montesquieu's Lettres Persanes (I72I), a work that satirizes Parisian society through the eyes of Persian visitors. The alleged I 854 "Chief Seattle Statement" (posted online at http://www.mountainman.com.au/thchief2.html, among other places) was popular among US counterculture movements in the I970s. The most famous fictive account of the twentieth century is anthropologist Carlos Castañeda's work, beginning with The Teachings of Don Juan (1968), which documents his training with a Yaqui shaman. His work was hugely popular with New Age, countercultural movements from the r970s.

3 An interesting illustration of vā and social respect is evident in the YouTube documentary Moana Premiere in Samoa with Auli'i Cravalho (TheCoconetTV 20I6), which includes vox-pop interviews with Samoans about what they thought of the movie Moana. A young man says, "I have some issues with the character Māui." Those familiar with the memes criticizing Māui's large size in the movie would, like us, anticipate this to be his issue. Instead, the young man says, "I don't like his attitude. He can be a bit gung-ho at times"-suggesting that Māui's selfinterest and lack of regard for others make him an unattractive demigod.

\section{References}

Alexeyeff, Kalissa

2000 Dragging Drag: The Performance of Gender and Sexuality in the Cook Islands. The Australian Journal of Anthropology I I (2): 297307 .

2009 Dancing Sexuality in the Cook Islands. In Transgressive Sex: Subversion and Control in Erotic Encounters, edited by Hastings Donnan and Fiona Magowan, II3-I30. New York: Berghahn Books.

20I6 Re-Purposing Paradise: Tourism, Image and Affect. In Touring Pacific Cultures, edited by Kalissa Alexeyeff and John Taylor, 403422. Acton, АСт: ANU Press. 
Anae, Melani

20Iо Teu Le Va: Toward a "Native" Anthropology. In Genealogies: Articulating Indigenous Anthropology in/of Oceania, edited by Ty $\mathrm{P}$ Kāwika Tengan, Tēvita O Ka'ili, and Rochelle Tuitagava'a Fonoti. Bhabha, Homi Special issue of Pacific Studies 33 (2/3): 222-240.

I984 Of Mimicry and Man: The Ambivalence of Colonial Discourse. In Discipleship: A Special Issue on Psychoanalysis, edited by Joan Copjec. Special issue of October 28:I25-I33.

Butler, Judith

I990 Gender Trouble: Feminism and the Subversion of Identity. New York: Routledge.

I993 Bodies That Matter: The Discursive Limits of "Sex." New York: Routledge.

Castañeda, Carlos

I968 The Teachings of Don Juan: A Yaqui Way of Knowing. Berkeley: University of California Press.

Deckard, Sharae

2010 Paradise Discourse, Imperialism, and Globalization: Exploiting Eden. New York: Routledge.

Errington, Frederick, and Deborah Gewertz

I989 Tourism and Anthropology in a Post-Modern World. Oceania 60 ( I): 37-54.

Gómez-Peña, Guillermo, and Coco Fusco

I992-I994 The Couple in a Cage: Two Undiscovered Amerindians Visit

the West. Performance art, multiple locations.

Heredia, Paula, and Coco Fusco, directors

1993 The Couple in the Cage. Documentary, 34 minutes. https://vimeo .com/79363320. [accessed I7 Feb 2018]

Jolly, Margaret

I997 From Point Venus to Bali Ha'i: Eroticism and Exoticism in Representations of the Pacific. In Sites of Desire, Economies of Pleasure: Sexualities in Asia and the Pacific, edited by Leonore Manderson

Kaplan, E Ann and Margaret Jolly, 99-I22. Chicago: University of Chicago Press.

I997 Looking for the Other: Feminism, Film, and the Imperial Gaze. New York: Routledge.

Kelly, John D

I997 The Gaze and the Grasp: Plantations, Desires, Indentured Indians, and Colonial Law in Fiji. In Sites of Desire, Economies of Pleasure, edited by Leonore Manderson and Margaret Jolly, 72-98. Chicago: University of Chicago Press. 
Kihara, Shigeyuki, and Natalie Poland

2013 Shigeyuki Kihara: Undressing the Pacific; A Mid-Career Survey Exhibition. Hocken Collections at University of Otago, Dunedin, New Zealand, 20 April-8 June.

Kihara, Yuki

2OI2 Culture for Sale. Performance and multimedia installation. Campbelltown Arts Centre, Sydney, Australia, I3 January-ı 8 March.

2013 Where Do We Come From? What Are We? Where Are We Going? Performance and photo display. Milford Galleries Dunedin, New Zealand, I 6 March-ıo April.

20I 5 A Study of a Samoan Savage. Photographic and video series. Multiple dates and venues.

2016 Der Papālagi (The White Man). Performance, photography, and film. Multiple dates and venues. Preview available from: https://www .milfordgalleries.co.nz/dunedin/submissions/I032 I-9b5290a9 [accessed 4 Aug 20I7]

Latai, Latu

20I4 From Open Fale to Mission Houses: Negotiating the Boundaries of "Domesticity" in Samoa. In Divine Domesticities: Christian Paradoxes in the Asia Pacific, edited by Hyaeweol Choi and Margaret Jolly, 299-323. Acton, ACT: ANU Press.

Livingston, Jennie

I990 Paris Is Burning. Documentary, 78 minutes. Distributed by Miramax Films.

Lott, Eric

20I3 Love and Theft: Blackface Minstrelsy and the American Working Class. Oxford, uk: Oxford University Press.

Meleiseā, Mālama

I987 The Making of Modern Samoa: Traditional Authority and Colonial Administration in the History of Western Samoa. Suva: Institute of Pacific Studies of the University of the South Pacific.

Montesquieu, Charles de Secondat, Baron de

I72I Lettres Persanes. Amsterdam: Pierre Brunel.

Ohnuma, Keiko

2002 Local Haole-A Contradiction in Terms? The Dilemma of Being White, Born and Raised in Hawai'i. Cultural Values [now titled

Okamura, Jonathan Y Journal of Cultural Research] 6 (3): 273-285.

I994 Why There Are No Asian Americans in Hawai'i: The Continuing Significance of Local Identity. In The Political Economy of Hawai $i$, edited by Ibrahim G Aoudé. Special issue of Social Processes in Hawai'i 35:I6I-I78. 
O’Rourke, Dennis, director

I988 Cannibal Tours. Documentary film, 72 minutes. Canberra: O'Rourke \& Associates Filmmakers Pty Ltd.

Paasche, Hans

I988 Die Forschungsreise des Afrikaners Lukanga Mukara ins Innerste Deutschland. Reprint, edited by Franzisckus Hahnel, epilogue by Iring Fetscher. Munich: Goldman. Originally published in I9I2-I3.

Rohrer, Judy

2010 Haoles in Hawai'i. Honolulu: University of Hawai'i Press.

Roller, Jochen, and Yuki Kihara, artistic directors

2015 Them and Us. Dance performance and film, with dancers from the

TATAU Dance Group. Premiered at Sophiensaele Theater in Berlin. Preview at http://www.jochenroller.de/en/them-and-us/ [accessed I7 Feb 2018]

Sandlin, Jennifer A, and Julie Garlen Maudlin

2015 Disney's Pedagogies of Pleasure and the Eternal Recurrence of Whiteness. Journal of Consumer Culture I7 (2): 397-4I2.

Scheurmann, Erich

2007 Tuiavii's Way: A South Sea Chief's Comments on Western Society. Adapted and translated into English by Peter C Calveti. Revised and updated edition. Toronto: Legacy Editions. First published as Der Papalagi die Reden des Südseehäuptlings Tuiavii aus Tiavea. Buchenbach: Felsenverlag (I920).

Senft, Gunter

I999 Weird Papālagi and a Fake Samoan Chief: A Footnote to the Noble Savage Myth. Rongorongo Studies: A Forum for Polynesian Philol-

Silverman, Eric ogy 9 (I/2): 23-32; 62-75.

2013 After Cannibal Tours: Cargoism and Marginality in a Post-Touristic

Tcherkézoff, Serge

Sepik River Society. The Contemporary Pacific 25 (2): 22 I-2 58

2009 A Reconsideration of the Role of Polynesian Women in Early Encounters with Europeans: Supplement to Marshall Sahlins' Voyage Around the Islands of History. In Oceanic Encounters: Exchange, Desire, Violence, edited by Margaret Jolly, Serge Tcherkézoff, and Darrell Tryon, II3-I60. Acton, АCT: ANU Press.

Tengan, Ty Kāwika, and Lamakū Mikahala Roy

2014 "I Search for the Channel Made Fragrant by Maile": Genealogies of Discontent and Hope. Oceania 84 (3): 3 I 5-330.

TheCoconetTv

2016 Moana Premiere in Samoa with Auli $i$ Cravalho. YouTube video, i 8 
Dec. https://www.youtube.com/watch?v=FIXa6otA2Sc [accessed I June 2017]

Thode-Arora, Hilke, editor

20I4 From Samoa with Love? Samoan Travelers in Germany, I895-I9I I: Retracing the Footsteps. Munich: Museum Fünf Kontinente, Hirmer.

Torgovnick, Marianna

I990 Gone Primitive: Savage Intellects, Modern Lives. Chicago: The University of Chicago Press.

Treagus, Mandy

2016 Yuki Kihara's Culture for Sale and the History of Pacific Cultural Performance. In Touring Pacific Cultures, edited by Kalissa Alexeyeff and John Taylor, I4I-I66. Acton, ACT: ANU Press.

Urry, John

I990 The Tourist Gaze: Leisure and Travel in Contemporary Societies. London: Sage.

Wattie, Nelson

I992 Two German Views of Samoa. In Us/Them: Translation, Transcription and Identity in Post-Colonial Literary Cultures, edited by Gordon Collier, I7-24. Amsterdam: Rodopi.

\section{Abstract}

Yuki Kihara's 2016 work Der Papālagi (The White Man) provides a critical reappropriation of an early twentieth-century account of a Samoan chief and his views on "white people" and the artifice of European "civilization." This work was popular as an invocation of island paradise that appealed to German sensibilities of the time. It has, however, been revealed as a literary masquerade written by Erich Scheurmann, who resided briefly in Sāmoa in the early twentieth century. This tale has been further interpreted in a photographic project by artist Yuki Kihara who uses it to reexplore contemporary evocations of paradise and to disrupt hierarchical relations through a series of racial crossings and inversions of looking at relations that work to provincialize boundaries of race and question understandings of cultural appropriation. In both Scheurmann's and Kihara's works, as well as in the collaborative project of writing this essay, the dynamics of possessing paradise via colonial imaginaries, neocolonial leisure industries, and the practice of ethnography are explored to highlight the complexities of exploitation, cultural ownership, and desire.

KEYWORDS: race, neocolonialism, Sāmoa, cultural appropriation, paradise, crossdressing performances 